\title{
KONVERZIÓ ALAPÚ, ONLINE KÖZPONTÚ BTL KOMMUNIKÁCIÓS STRATÉGIA MEGALAPOZÁSA AZ ÉPÍTŐIPARI VÁLLALKOZÁSOK ESETÉBEN
}

\section{ESTABLISHMENT OF A CONVERSION-BASED, ONLINE- CENTERED BTL COMMUNICATION STRATEGY FOR BUSINESSES IN THE CONSTRUCTION INDUSTRY}

\author{
Máté Balázs ${ }^{1}$, Csonka Nikoletta ${ }^{2}$ \\ ${ }^{1}$ Szent István Egyetem Gazdaság- és Társadalomtudományi Kar, H-2100, Magya- \\ rország, Gödöllö, Páter Károly u. 1. mate@marketingprofesszorok.hu \\ ${ }^{2}$ Marketingpfesszorok Kft., Gödöllö H-2100, Magyarország, Gödöllö, Kossuth Lajos \\ ut. 13
}

\begin{abstract}
In this study, we examine the factors that best facilitate the establishment of a successful, conversionbased marketing strategy in the construction industry, and int he case of manufacturers. We aim to identify the channels, devices and elements of communication that are best suited to getting our message across. Our research project - which relied on literature on this topic - took the form of a quantitative study on consumers' preferred information channels and the most relevant factors in their decision making processes. We outline a proposed communication strategy based on the conclusions We've drawn from respondents' replies.
\end{abstract}

Keywords: online marketing, marketing in the construction industry, conversion-based BTL communication.

\section{Összefoglalás}

Jelen publikációnkban azt vizsgáljuk, hogy milyen tényezők mentén lehetséges és érdemes kialakítani sikeres, konverzió központú marketing stratégiát az építőipari vállalkozások, gyártók esetében. Célunk meghatározni, hogy melyek azok a kommunikációs elemek, amelyek kiemelésével sikeressé tehető a kommunikáció, illetve hogy melyek azok a csatornák, eszközök amelyekkel hatékonyan érhetjük el célközönségünket. Kutatómunkánk során - támaszodva a szakirodalomra - kvantitatív kutatást végeztünk a fogyasztók körében a tájékozódásra felhasznált csatornákról és a döntéshozatali mechanizmust befolyásoló tényezőkröl. A válaszok alapján levont következtetésekkel mutatunk irányt a kommunikációnak.

Kulcsszavak: online marketing, marketing az épitöiparban, konverzió alapú BTL kommunikáció. 


\section{A téma aktualitása és szakiro- dalmi kötődése}

Tanulmányunk aktualitását a 2008-as év második felében kirobbanó, és azt követően fokozatosan elmélyülő pénzügyi-gazdasági válság generálta, amely az építőipar fejlődését is negatív irányban befolyásolta köszönhetően a fizetőképes kereslet radikális csökkenésének. [1]

A KSH adatai alapján elmondhatjuk (1. ábra), hogy az építőipari termelés volumenváltozását illetően a 2012-es év bizonyul pozitívnak, ahonnan fejlődés látható. A válság előtti korszak eredményeit azonban még 2014-ben sem közelítette meg az ágazat. [2]

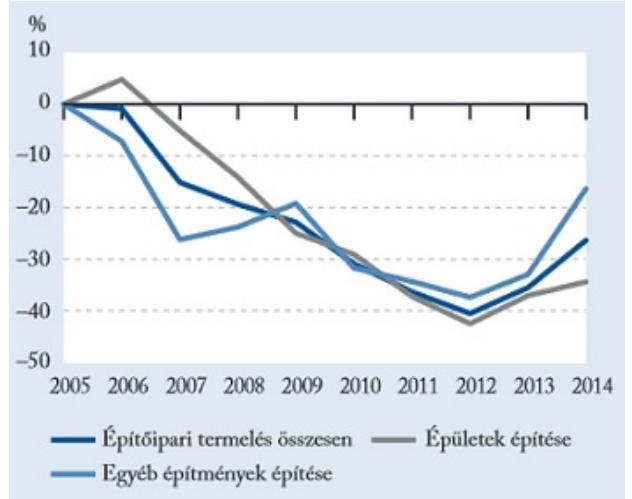

1. ábra. Az építőipari termelés volumenváltozása 2005. évhez képest. In.: KSH Magyarország 2014 (2015); ISSN: 14162768; 177. oldal

Az ágazatban, a folyamatosan életbe lépő változásoknak köszönhetően szükségszerüen kialakult egy igen éles versenyhelyzet. A nagyvállalati szektorban a külföldi tulajdonban lévő vállalatok jelenléte kimondottan erős [3] így főként a KKV szektor fellendítésének lehetőségeit vesszük górcső alá. A KKV szektor sajátosságait tekintve ilyen módon a BTL kommunikációs stratégia kialakítását helyezzük elötérbe. Természetesen az ágazat fellendítése esetében nem hagyhatjuk figyelmen kívül az építőipari beruházások projektkockázatait sem, hiszen ezek, úgy mint a termék vagy szolgáltatás minősége és egyéb tulajdonságai, meggátolhatják a sikeres értékesítést. Ezekre a tényezőkre azonban olyan modelleket tártak fel korábbi kutatások alapján, amelyek az egész szektorra kiterjedően vizsgálják - és lehetőség szerint kezelik - a leggyakrabban előforduló kockázati tényezőket, mint például a pénzügyi-, az idő-, a személyi-, a társadalmi- és a pszichológiai kockázati tényezőket. [4]

Ezen tényezők tompítására a kommunikáció során is törekednünk kell - a komplex, konverzióközpontú BTL kommunikációs stratégia kialakításához azonban ennél több információra van szükségünk.

\section{Módszertani háttér}

Primer kutatásunk során kérdőíves mintavétellel vizsgáltuk, hogy milyen felületen érdeklödnek a kitöltők az építőanyagok iránt, és milyen szempontokat vesznek figyelembe a vásárláskor - mik azok a hívószavak, amelyek jelentősen befolyásolják a vásárlási hajlandóságot. Kvantitatív kutatásunk eredményei alapján vázolunk fel egy lehetséges utat a BTL kommunikációs stratégia kialakítására az építőipari alapanyagok gyártói esetében.

\section{Eredmények}

Kérdöívünket online tettük közzé, amely felületen összesen 239 válasz érkezett. Fontosnak találtuk meghatározni, hogy válaszadóink milyen módon kapcsolódnak az építőiparhoz. Az összes válaszadó közül 23 fö dolgozik az építőiparban, 82 fó építkezett a közelmúltban, és 46 fö tervez építkezést a közeljövőben. A fennmaradó 107 fö közvetlenül nem érintett az építőiparban és az építőipari anyagokban. 


\subsection{Hatékonyan használható csator- nák megállapítása}

A kutatás eredményei alapján elmondhatjuk, hogy a megkérdezettek 64\%-ka használná a Google keresőjét az építőipari alapanyagok kiválasztása esetében - így a keresőoptimalizált weboldal létrehozása és müködtetése kiemelt szerepet kap. 56\%-uk támaszkodik az ismerősök ajánlásával, amelyet a közösségi média marketing segítségével könnyedén meg is lovagolhatunk: a vélemények, megosztások mind nagyszerü fórumot biztosítanak ennek. Önmagában a Facebook-ot ugyan csak $8 \%$ használná tájékozódásra, ez nem jelenti azonban azt, hogy push módszerrel nem találhatunk meg ennél jóval több embert az említett felületen. Az ATL kommunikációs eszközök, a televíziós reklámok ebben az esetben is elenyésző eredményt mutatnak, csupán a megkérdezettek 7\%-a informálódik ilyen felületröl. Kijelenthetjük tehát, hogy a tv megjelenés ma már csak PR célokra alkalmas - köszönhetően az érdeklődési aránynak és a mérhetőség elmaradásának - annak viszont jóval drágább, mint már eszközök. Az online újságok, portálok cikkeit a megkérdezettek $27 \%$-a tartja megfejelö forrásnak a tájékozódásra: ezek nem csak jóval költséghatékonyabbak a TV megjelenéseknél, de eredményeit a jól beállított, konverziómérésre alkalmas honlappal pontosan mérhetjük. A kiállítások és bemutató termek függetlenül a BTL kommunikációtól úgy tünik, nem elhanyagolhatóak. A megkérdezettek $23 \%$-a nyilatkozott úgy ugyanis, hogy felkeresne bemutató termeket, és $14 \%$ érdeklődött a kiállítások iránt.

\subsection{Kommunikációs hívószavak, dön- tést befolyásoló tényezők megha- tározása}

Kutatásunk során szerettünk volna irányt mutatni annak is, hogy milyen kommunikációs hívószavakat használhatunk stratégiánk során.
A válaszok alapján elmondhatjuk, hogy az ár/érték arány döntő szerepet játszik (89\%), karöltve a minőséggel, amelyet a válaszadók 77\%-a jelölt meg. A gyártó hírneve azonban csupán a megkérdezettek 10\%-ánál minősül befolyásoló tényezőnek. A termék ismertsége ennél többeket érdekel, a válaszadók $15 \%$-a jelölte meg, míg a minősítések megléte és kommunikációja a kitöltők 22\%-át érdekelte kiemelten. Ígéretes azonban, hogy a környezetvédelmi szempontokra, úgy tünik, érdemes odafigyelniük a gyártóknak: $31 \%$ értékelte úgy, hogy számára kiemelten fontos ez a tényező a döntéshozatal során!

Külön kérdésben vizsgáltuk a haza termékek preferenciáját. Más ágazatokban a honi termékek preferenciájának megteremtődése már kialakulóban van [5] ugyan, gazdaságunk szempontjából ez továbbra is stratégiai fontosságú kérdés. Kutatásunk eredményeként elmondhatjuk, hogy a megkérdezettek 41\%-a szerint meghatározó tényező csupán, hogy a vásárolt termék magyar gyártótól érkezik-e.

\section{Következtetések}

Kutatásunk eredményei alapján meghatározzuk, hogy melyek azok a kommunikációs elemek, amelyek a sikeres BTL kommunikációs stratégia részeként segítik elő a növekedést az építőipari alapanyagok gyártói esetében.

A SEO központú, konverziómérésre alkalmas weboldal létrehozása kulcsfontosságú kérdés. A jól keresőoptimalizált weboldal a Google találatok segítségével közvetlen vásárlásokat generálhat, és ezen gondolatmeneten tovább haladva megállapíthatjuk, hogy az AdWords hirdetések rendszerét is kiváló eredményekkel használhatjuk. A konverziómérés segítségével olyan hatékony kampányt hozhatunk létre, amelyben pontosan meghatározhatjuk, hogy mennyit költünk (költhetünk) egy konverzióra, megrendelésre így kialakítva a pozitív ROI-t. A 
hirdetésoptimalizálást segíti a SEO teljesítmény köszönhetően az ilyen módon támogatott minőségi mutatónak, amely az AdWords rendszerében olcsóbb kattintásonkénti árat eredményez.

A tartalommarketing a keresőoptimalizálás igényével karöltve jelenik meg elsőként, de ennél is tovább mutat: azon kívül, hogy a szöveges tartalom segíti az oldal SEO-jának felépítését, a szakértői cikkek a fogyasztók körében bizalmat ébresztenek hiszen mutatják a gyártó szakértelmét. Külsős portálokon is érdemes bevezetni a PR cikkek rendszerét, ahol független szakértőként mutathatjuk be az adott vállalat termékét, ezzel generálva vásárlókat - és természetesen értékes linkeket, amelyek a cikkben elhelyezve a hivatkozott céloldal keresőoptimalizáltságát segíti elő.

A közösségi média napjainkban minden BTL kommunikációs stratégia egyik alapköve. Bár a válaszadóknak csak kis százaléka jelölte meg a Facebook-ot, mint tájékozódási felületet, ez nem feltétlen releváns információ - köszönhetően a Facebook felhasználói szokásainak. Hiszen ezt a felületet kihasználva, a célközönség érdeklődését megragadó érdekes, informatív tartalmakat is megoszthatunk, amelyeket nem keresnek direkt - mégis elérést generál. A megosztásoknak köszönhetően pedig nem független oldaltól kapja az információt a fogyasztó, hanem közvetlenül ismerősétől!

Kommunikációnk középpontjába első sorban a minőséget és az ár/érték arányt érdemes helyezni. Ez számos összehasonlí- tó jellegü, vagy egyéb informatív PR cikknek és tartalomnak adhat témát. A hazai termék preferenciája önmagában nem kiemelkedő, ahogy a környezetvédelmi szempontok is csupán 31\%-ban bizonyulnak döntést meghatározó tényezönek, a kettő együtt való kommunikálása, az összefüggések feltárása azonban már hozhat eredményeket. A gyártó hírnevét bár nem tartják kiemelten fontosnak, PR jellegü megjelenésekkel érdemes más tényezőkkel együtt építeni a brandet, amellyel a termék ismertségét is növelhetjük.

\section{Szakirodalmi hivatkozások}

[1] Kapronczai I., Udovecz G.: A magyar agrárgazdaság helyzete. Gazdálkodás folyóirat, 53. évfolyam 6. szám, 2009, 530 - 543. oldal.

[2] Központi Statisztikai Hivatal: Magyarország 2014, Központi Statisztikai Hivatal, Budapest, 2015, 177. oldal

[3] Parragh B.: Marketingstratégia vállalati versenyképességhez való hozzájárulása, Marketingstratégiai javaslatok szekunder és primer piackutatás alapján. Óbudai Egyetem Keleti Károly Gazdasági Kar, Vállalkozásmenedzsment Intézet, Budapest, 2011

[4] Szilágyi T. P., Almádi B., Tóth T.: Az épitóipari, beruházási - projekt kockázatok vizsgálata és feltárt dimenziói. XX. Fiatal Müszakiak Tudományos Ülésszakasza, 2015 Kolozsvár, 287-290

[5] Lehota J., Fürediné Kovács A.: A madárinfluenza piaci hatásainak vizsgálata húsboltok vezetöivel készitett interjúk alapján, AVA 3 Konferencia, Debrecen, 2007. március 2021., ISBN 978-963-87118-7-8 